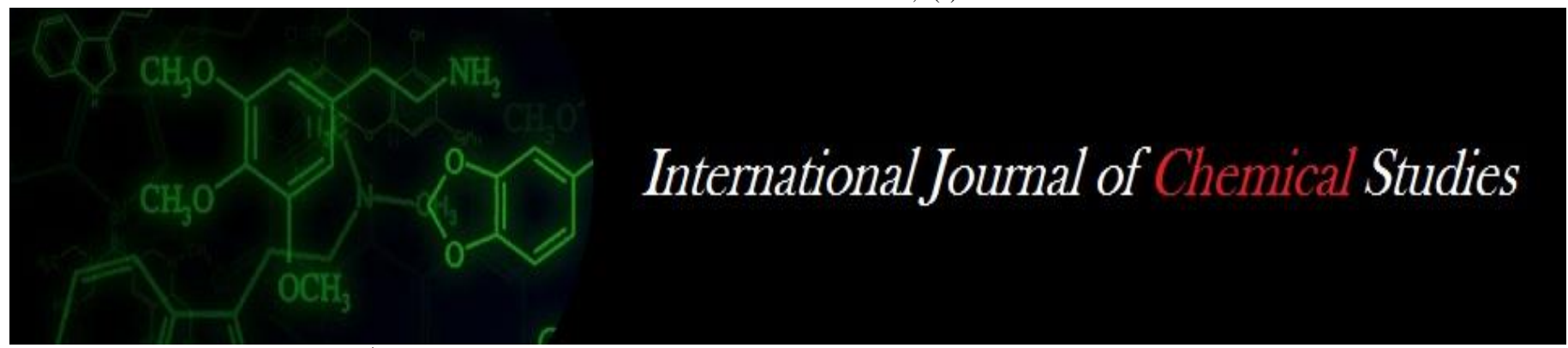

P-ISSN: 2349-8528

E-ISSN: 2321-4902

www.chemijournal.com

IJCS 2020; 8(6): 2096-2098

(C) 2020 IJCS

Received: 18-08-2020

Accepted: 27-09-2020

Tegbir Singh

School of Agriculture, Lovely

Professional University,

Phagwara, Punjab, India

Dr. Gurpreet Singh

School of Agriculture, Lovely

Professional University,

Phagwara, Punjab, India
Corresponding Author:

Tegbir Singh

School of Agriculture, Lovely

Professional University,

Phagwara, Punjab, India

\section{Weed flora in wheat (Triticum aestivum): A review}

\author{
Tegbir Singh and Dr. Gurpreet Singh
}

DOI: https://doi.org/10.22271/chemi.2020.v8.i6ad.11082

\begin{abstract}
The different weed flora found in different experimental fields of wheat were Phalaris minor, Melilotus indica, Stellaria media, Anagallis album, Lolium temulentum, Avena ludoviciana, Salvia anthemifolia, Chenopodium album, Polypogon fugax, Cynodon dactylon and Cyperus rotandus. Avena ludoviciana, Lolium temulentum, Polypogen monspeliensis, Poaannua, Sonchusarvensis Asteraceae, Carthamusoxyacantha, Cichoriumintybus, Euphorbia simplex, Asphodelus tenuifolius, Chenopodium murale, Chenopodiastrum murale, Lathyrussativus, Lathyrus aphaca, Vicia sativa, Viciahir suta, Medicago denticulata, Trigonella polycerata, Melilotus alba, Melilotus indica, Anagallis arvensis, Spergula arvensis, Stellaria media, Saponaria vaccaria, Silene conoidea, Fumaria parviflora, Argemone mexicana, Coronopus didymus, Sisymbrium irio, Malva parviflora, Veronica agrestis, Lithospermum arvense, Antirrhinum orontinum, Gnaphalium purpureum, Cannabis sativa, Oenothera laciniata, Arenaria serpyllifolia and Ranunculus sceleratus.
\end{abstract}

Keywords: Wheat, weed flora, sedges, leaves etc.

\section{Introduction}

Wheat (Triticum aestivum) is one of the most important grain crop which is grown in approximately 225 million ha worldwide, about half of which is in the developing countries (Pisal and Sagarka, 2013) ${ }^{[17]}$. India is the second largest producer of wheat in the world contributing about 94.88 milloin tons of grains with productivity of 2.98 tonnes per hac from the area of 31.5 milloin ha (Chhokar et al., 2012) ${ }^{[2]}$.

The high nutrient and water requirements along with less competitive nature of these high yielding dwarf varieties have provided the conducive environment for increased weed infestation. Weeds are regarded as most disdain to crop production and account for about one third of total losses caused by all the pests. Among various wheat based cropping system, ricewheat is major one, occupying about 10.0 million hectare in India and worldwide this system occupies about 24 million hectare area (Ladha et al., 2000; Timsina and Connor, 2001) ${ }^{[9,21]}$. Weeds cause significant annual regional productivity losses in rice-wheat system (Harrington et al., 1992) [6]. Weed infestation is one of the major factors limiting crop productivity. For realizing full genetic yield potential of the crop, the proper weed control is one of the essential ingredients. Weeds not only reduce the yield but also make the harvesting operation difficult. Therefore, for sustaining food grain production to feed ever-increasing population and ensuring food security, effective weed management is very essential.

Weed competition Introduction of high yielding dwarf wheat varieties changed the spectrum of weed flora from dominance of broadleaf weeds in the 1960s to mixed flora of broadleaf and grassy weeds in early 1970s and then the dominance of grass weeds especially, Phalaris minor in late 1970s. The chemical weed control, therefore, became a necessity in late 1970s. Herbicides were introduced in 1979-80, weed flora changed in favor of complex weeds species in late 1980s and then again in favor of Phalaris minor during the early 1990s with evolution of herbicide resistance (Malik and Singh, 1993) ${ }^{[10]}$. Weeds have enjoyed dominance over crop basically because of poor agronomic management. To introduce good agronomic practices and the ecology, it is important to understand the competition between weeds and the wheat crop. Weeds compete with crop plants for moisture, nutrients, light and space, thereby depriving the crop of vital inputs. Therefore, weed competition is one of the most important constraints in crop production. 
Weed-crop competition begins when crop plants and weeds grow in close proximity and their root or shoot system overlaps. The competition becomes severe due to more smothering effect, when weeds emerge earlier than the crop. In rice-wheat system, due to enough soil moisture after harvesting of rice, weeds emerge earlier than wheat or along with wheat crop. Losses in wheat yield are primarily due to reduction in tillering. The critical period of weed control in wheat is 30-45 days after sowing and crop should be kept weed free during this period. Majority of the farmers are not adhering to this critical period for the management of weeds and they mostly delay the herbicide application.

\section{Different types of weeds in wheat}

Govindra et al., (2002) ${ }^{[4]}$ observed that the dominated weed florain wheat from MP were Phalaris minor, Chenopodium album, Melilotus indica, Anagallis arvensis, Fumaria parviflora, Medicago denticulate and Lathyrus aphaca.

Singh et al., (2005) ${ }^{[20]}$ observed the weeds in wheat like, Chenopodium album, Melilotus alba, Spergullaarvensis, Phalaris minor, Cyperusrotandus and Cynodondactylon.

Rajkhowa et al., (2005) ${ }^{[18]}$ were observed major weed flora in wheat like Spilanthespaniculata (11\%), Ageratum houstonianum (17\%), Oxalis debilis var. corymbosa (15\%), Solanum indicum (4\%), Chenopodium album (3\%), Cynodon dactylon (28\%), Setari apumila (6\%) and Paspallum conjugatum (15\%).

Malik et al., (2005) [11] observed infestationweed flora in wheat in their experimental field with grassy $(65 \%)$ as well as broadleaf weeds (35\%). Among grassy weeds, Artemisia ludoviciana was the major weed $(80 \%)$ along with Phalaris minor (20\%) whereas broadleaf weeds comprised mainly Chenopodium album (40\%), Amaranthusretroflexus (15\%), Coronopus didymus (20\%), Meliltus alba (15\%) and miscellaneous weeds (10\%).

Mishra et al., (2005) [12] observed weeds of wheat like,aegyptium, Paspalum distichum, Ischaemum rugosumand Eragrostis japonica among the grasses; Cyperusiria, $C$. rotundus, Fimbristylismiliaceae, Scirpuslateriflorus, and Eriocaulonquinquangulare, among the sedges; and Caesuliaaxillaris, Eclipta alba, Ammania baccifera, Cynotisaxillaris, Commelina communis, Alternanthera philoxeroides, A. sessilis, Monochoriavaginalis, Linderina crustacean, Hydroleazeylanica, Ludwigiaoctovalvis, Oldenlandia dichotoma and Spilanthusclava, among broad leaved weeds.

Pandey et al., (2006) ${ }^{[16]}$ reported that weeds in wheat such as Melilotusindica, Stellaria media, Anagallis album, Lolium temulentum, Avena ludoviciana, Salvia anthemifolia, Chenopodium album, Polypogon fugax, Cynodon dactylon and Cyperus rotandus.

Kanogia and Nepalia (2006) ${ }^{[8]}$ observed that flora of wheat like Phalaris minor, Chenopodium album, Chenopodia strummurale, Convolvulus arvensis, Anagallis arvensis, Melilotus indica and Spergula arvensis.

Pandey et al. (2006) ${ }^{[16]}$ recorded maximum weed density in wheat in Phalaris minor (29.3\%), Melilotus indica $(7.8 \%)$, Anagalis arvensis (11.1\%) and Coronopus dydimus (20.3\%). Pandey and Dwivedi (2007) ${ }^{[15]}$ reported weed flora in wheat that Chenopodium album (40\%), Phalaris minor (2\%), nutgrass $(22 \%)$ and dubgrass $(8 \%)$.

Ormeno and Diazo (2007) ${ }^{[14]}$ were observed the major grassy weeds infestimg in wheat wild oat, rye grass, dogtail and bulbous oat grass.
Mishra and Singh (2007) observed weed flora in wheat Echinochloa colona and Commmelina sp. and Phalaris minor, Cyperus difformis, Ammania baccifera and Eriocaulon spp.

Bharat and Kachroo (2007) ${ }^{[1]}$ observed the occurrence of grassy weeds in wheat such as annua, Phalaris minor and broad leaf such as Anagallis arrvensis, Trachyspermum spp and Euphorbia helioscopia.

Gaffer et al., (2008) [3] reported weed flora in wheat Chenopodium album, Melilotus indica, Anagallis arvensis, Fumaria parviflora, Medicago denticulate.

Tuti and Das (2011) ${ }^{[22]}$ at New Delhi (IARI) observed that major weed flora in wheat at the experimental field are Chenopodium album, Melilotus indica, Avena sterilisssp, Indoviciana (Dur) among grasses and Cyperus rotundus among sedges.

Jha and Kewat (2011) ${ }^{[7]}$ reported that the dominating weed species in wheat were identified as Echinochloa colona, Echinochloa glabrescens, Echinochlo acrusgalli, Eleusine indica, Panicum repens, Digitaria sanguinalis, Dactyloctenium aegyptium, Paspalum distichum, Ischaemumrugosum and Eragrostis japonicaamong the grasses; Cyperus iria, Cyperus difformis, Cyperus rotundus, Fimbristylis Miliaceae, Scirpuslateriflorus, and Eriocaulonquinquangulare, among the sedges; and Caesuliaaxillaris, Eclipta alba, Ammania baccifera, Cynotisaxillaris, Commelina communis, Alternanthera philoxeroides, A. sessilis, Monochoria vaginalis, Linderina crustacean, Hydrolea zeylanica, Ludwigia octovalvis, Oldenlandia dichotoma and Spilanthus clava, among broad leaved weeds.

Singh and Singh (2012) observed weed flora in wheat that aegyptium, Paspalum distichum, Ischaemum rugosum and Eragrostis japonica among the grasses; Cyperus iria, Cyperus difformis, Cyperusrotundus, Fimbristylismiliaceae, Scirpuslateriflorus, and Eriocaulonquinquangulare, among the sedges; and Caesuliaaxillaris, Eclipta alba, Ammaniabaccifera, Cynotisaxillaris, Commelina communis, Alternanthera philoxeroides, A. monochoriavaginalis, Linderina crustacean, Hydroleazeylanica, Ludwigiaoctovalvis, Oldenlandiadichotoma and Spilanthusclava, among broad leaved weeds.

Pisal and Sagarka (2013) ${ }^{[17]}$ observed monocot weeds in wheat such as, Brachiaria serrate, Echinochloa colonum and dicot weeds viz Amaranthusviridis, Digera arvensis, Chenopodium album, Euphorbia hirta and seldges viz Cyperus rotundus.

Singh et al., (2013) ${ }^{[19]}$ reported that the weeds in wheat like, Echinochloa colona, Echinochloa glabrescens, Echinochloa crusgalli, Eleusine indica, Panicum repens, Digitaria sanguinalis, Dactyloctenium aegyptium, Paspalum distichum, Ischaemumrugosum and Eragrostisjaponicaamong the grasses; Cyperus iria, Cyperus difformis, Cyperus rotundus, Fimbristylis Miliaceae, Scirpuslateriflorus, and Eriocaulonquinquangulare, among the sedges; and Caesuliaaxillaris, Eclipta alba, Ammania baccifera, Cynotisaxillaris, Commelina communis, Alternanthera philoxeroides, Monochoria vaginalis.

Singh and Saxena (2013) ${ }^{[19]}$ reported that weed flora in wheat such as Melilotusindica, Stellaria media, Anagallis album, Lolium temulentum, Avena ludoviciana, Salvia anthemifolia, Chenopodium album, Polypogon fugax, Cynodon dactylon and Cyperus rotandus. 


\section{Conclusion}

The size of misfortunes generally relies on the piece of weed venture, time of harvest, weed rivalry and their capacity to compete for the essential components with crop plants. Different weeds that are commonly in wheat crop are Phalaris minor, Melilotus indica, Stellaria media, Anagallis album, Lolium temulentum, Avena ludoviciana, Salvia anthemifolia, Chenopodium album, Polypogon fugax, Cynodon dactylon and Cyperus rotandus. Avena ludoviciana, Lolium temulentum, Polypogen monspeliensis, Poaannua, Sonchus arvensis Asteraceae, Carthamusoxyacantha, Cichorium intybus, Euphorbia simplex, Asphodelus tenuifolius, Chenopodium murale, Chenopodiastrum murale, Lathyrus sativus, Lathyrus aphaca, Vicia sativa, Viciahir suta, Medicago denticulata, Trigonella polycerata, Melilotus alba, Melilotus indica, Anagallis arvensis, Spergula arvensis, Stellaria media, Saponaria vaccaria, Silene conoidea, Fumaria parviflora, Argemone mexicana, Coronopus didymus, Sisymbrium irio, Malva parviflora, Veronica agrestis, Lithospermum arvense, Antirrhinum orontinum, Gnaphalium purpureum, Cannabis sativa, Oenothera laciniata,, Arenaria serpyllifolia and Ranunculus sceleratus.

\section{References}

1. Bharat R, Kachroo D. Bio efficacy of various herbicides and their mixture on weeds and yield of wheat (Triticum aestivum) under subtropical agro- ecosystem. Indian Journal of Agronomy 2007;52(1):53-59.

2. Chhokar RS, Sharma RK, Pundir AK, Gathala MK. Non chemical Integrated Weed Management in Wheat (Triticum aestivum). Indian Journal of Weed Science 2012;25(3):112-116.

3. Gaffer MA, Khan EA, Alam MS, Adhikary SKM. Influence of planting density and time of weeding on weed infestation and yield performance in wheat. Bangladesh Journal of Science 2008;38(3):4880-483.

4. Govindra RP, Singh CG, Kumar SQ. Effect of herbicide on Phalaris minor and wheat yield. Indian Journal of Weed Science 2002;23(4):21-24.

5. Gupta HS, Gopinath K, Pandey AK. Integrated Weed Management in wheat (Triticum aestivum). Indian Journal of Weed Science 2008;25(3):112-116.

6. Harrington LW, Morris M, Hobbs PR, Singh VP, Sharma $\mathrm{HC}$, Singh RP et al. Wheat and rice in Karnal and Kurukshetra districts, Haryana, India. Exploratory survey report. Hisar, New Delhi, India Mexico and Philippines: CCS Haryana Agricultural University, Indian Council of Agricultural Research, Centro International de Mejoramiento de Maizy Trigo, and International Rice Research Institute, 1992, 40-42.

7. Jha SM, Kewat RS. Evaluation of carfentrazone ethyl+ metsulfuron methyl against broadleaf weeds of wheat. Indian Journal of Weed Science 2011;43:12-22.

8. Kanojia Y, Nepalia V. Effect of chemical weed control on nutritent uptake by wheat and associated weeds. Agricultural Science Digest 2006;26(2):141-143.

9. Ladha JK, Fischer KS, Hossain M, Hobbs PR, Hardy B. (Eds), Improving the productivity and sustainability of rice-wheat systems of the Indo-Gangetic Plains: A synthesis of NARS-IRRI partnership research. IRRI Discussion Paper Series No. 40.International Rice Research Institute, Makati City, Philippines 2000.

10. Malik RK, Singh S. Evolving strategies for herbicide use in wheat. Resistance and integrated weed management. Proceedings of Indian Society of Weed Science
International Symposium on Integrated Weed management for Sustainable Agriculture, 18-20 November, 1993, Hisar. India 1993;1:225-238.

11. Malik RS, Yadav A, Malik RK, Punia SS. Efficacy of flufenacet and metribuzin against weeds in wheat (Triticum aestivum). Indian Journal of Weed Science 2005;37(3\$4)171-174.

12. Mishra JS, Singh VP, Yaduaraju NP. Effect of tillage and weed control method on weeds and wheat in vertisols. Indian Journal of Weed Science 2005;37(2):522-523.

13. Mishra JS, Singh VP, Yaduaraju NP. Integrated weed management in wheat (Triticum aestivum). Indian Journal of Weed Science 2006;25(3)112-116.

14. Ormeno N, Diaz SJ. Clodinafop a new herbicide for the selective control of grass weeds in wheat control efficacy of on wildoat, annual rye grass, digital grass and bulbous oat grass. Agriculturatecnica Santiago 2007;52(2):106117.

15. Pandey IB, Deivedi DK. Effect of planning pattern and weed control methods on weed growth and performance of wheat (Triticum aestivum). Indian Journal of Agronomy 2007;523(3):235-238.

16. Pandey IB, Deivedi DK, Pandey RK. Efficacy of herbicides and fertilizer management on weed dynamics in wheat (Triticum aestivum). Indian Journal of Agronomy 2006;52(3):235-238.

17. Pisal RR, Sagarka RK. Integrated weed management in wheat with new molecules (Triticum aestivum). Indian Journal of Weed Science 2013;45(1):25-28.

18. Rajkhowa A, Singh S, Yadav AK, Balyan RS. Influence of rice residue management and planting techniques on herbicidal efficiency in relation to wheat (Triticum aestivum). Indian Journal of Weed Science 2005;41(3):95-98.

19. Singh B, Dhaka AK, Pannu RK, Kumar S. Integrated weed management-Astrategy for sustainable wheat production-A review, Agriculture review 2013;34(4):243-255.

20. Singh DK, Rathi AS, Kumar, Singh VP. Integrated weed management in irrigated wheat. Progressive Agriculture 2005;8(2):74-75.

21. Timsina J, Connor DJ Productivity and management of rice-wheat cropping systems: issues and challenges. Field Crops Research 2001;69:93-132.

22. Tuti MD, Das TK. Carry over effect of metribuzin applied to soybean on weeds and wheat (Triticum aestivum) under zero and conventionsal tillage. Indian Journal of Agronomy 2011;56(2):121-126. 